\title{
A COMPREHENSIVE REVIEW ON BARLERIA PRIONITIS (L.)
}

\author{
KAMINI SINGH, DEEPIKA SHARMA, GUPTA RS*
}

Department of Zoology, Reproductive Physiology Section, Center for Advanced Studies, University of Rajasthan, Jaipur, Rajasthan, India. Email: gupta_rs@hotmail.com

Received: 20 March 2017, Revised and Accepted: 28 August 2017

\section{ABSTRACT}

Barleria prionitis is a famous perennial plant commonly known as porcupine flower or Vajradanti. It is a shrub with yellow flowers and two flat seeds shielded with matted hairs, inhabit most parts of India. Various parts of the plant such as leaves, roots, aerial parts, flowers, and stems are used in the traditional system of medicine. Conventionally, various infusions are prepared using the plant parts and utilized for the treatment of different kinds of diseases. Owing to its incredible odontalgic property, it is extensively used in treating bleeding gums and toothache. From the pharmacological point, the plant has been effectively screened for antibacterial, antifungal, antiviral, anti-inflammatory, antifertility, antioxidant, enzyme inhibitory, hepatoprotective, antihypertensive, anticancer, and anticataract activities. Compounds such as tannins, saponins, glycosides, phenolic acids, phytosterols, and terpenes have been identified in the plant. The plant contains some specific compounds such as barlenoside, barlerine, acetylbarlerine, and balarenone and some common secondary metabolites such as lupeol, $\beta$-sitosterol, vanillic acid, and syringic acid. This review provides morphological, ethnomedical, pharmacological, and phytochemical data of the plant B. prionitis.

Keywords: Barleria prionitis, Odontalgic, Tannins, Saponins, Phytosterols, Ethnomedical, Pharmacological.

(C) 2017 The Authors. Published by Innovare Academic Sciences Pvt Ltd. This is an open access article under the CC BY license (http://creativecommons. org/licenses/by/4. 0/) DOI: http://dx.doi.org/10.22159/ajpcr.2017.v10i12.18587

\section{INTRODUCTION}

Barleria prionitis also known as the porcupine flower, which belongs to the family Acanthaceae and genus Barleria. It is native to India, also distributed widely throughout Asia including Malaysia, Pakistan, Philippines, Sri Lanka, Bangladesh, Yemen and tropical Africa [1,2] Sri Lanka and Eastern Southern and Central Africa. It is an erect, perennial, prickly, and evergreen shrub, usually single-stemmed, growing to about $1.5 \mathrm{~m}$ in height from a single taproot. Lateral roots branching in all directions. The leaves are up to 100 $\mathrm{mm}$ long and $40 \mathrm{~mm}$ wide, oval-shaped though narrow at both ends (ellipsoid). The base of the leaves is protected by three to five sharp, 10-20 $\mathrm{mm}$ long, pale-colored spines. The yellow-orange tubular flowers with several long protruding stamens. Flowers are packed in bunches tightly together at the top of the plant, but they also occur singly at the base of leaves. Seed capsule which

oval-shaped has two fairly large, flat seeds, shielded with matted hairs with a sharp pointed beak. Stems and branches are stiff and smooth and light brown to light gray in color $[3,4]$. The taxonomical classification of $B$. prionitis is given in Tables 1 and 2.

Scientific name - Barleria prionitis

Common name - Porcupine flower HABITAT

B. prionitis is commonly found in shrub jungles and wayside thickets from plains to $500 \mathrm{~m}$. Common. Tropical Africa, Tropical Asia Sri Lanka, Pakistan, India, Malaysia. It is commonly found in the following states of India-Andaman and Nicobar Islands, Andhra Pradesh, Assam, Bihar, Chhattisgarh, Delhi, Goa, Gujarat, Jharkhand, Karnataka, Kerala, Madhya Pradesh, Maharashtra, Orissa, Rajasthan,

Tamil Nadu, Uttarakhand, Uttar Pradesh, and West Bengal [5].

\section{RATIONALE AND NOVELTY OF THE STUDY}

\section{Ethnomedical information about $B$. prionitis}

Family Acanthaceae consists of a large number of medicinal plants and is well known for its use in ethnomedicine. The prionitis species of the genus Barleria provides a variety of traditions properties. The whole plant or its specific parts (leaf, stem, root, bark, and flower) have been utilized for the treatment of catarrhal affections [6], ulcer, whooping cough, inflammations, glandular swellings, urinary infection, jaundice, fever, stomach disorders, and as diuretic and tonic. It is likewise used in urinary infection, jaundice, hepatic obstruction, and dropsy, and the paste of the roots is applied to benefit to boils and glandular swellings. It is also utilized for the treatment of anemia, toothache, and bacterial disorders. The flora is, especially, well recognized for caring for bleeding gums and toothache. Due to its antiodontalgic property, it is as wellknown as "Vajradanti" [7]. Some tribal communities utilize the leaves for the treatment of piles and to control irritation. The plant is also utilized for the stiffness of limbs, enlargement of the scrotum, and sciatica [8-11].

\section{Pharmacological activities of $B$. prionitis}

Owing to its traditional use, B. prionitis has been studied for different types of pharmacological activities. Numerous in vitro and in vivo studies on different cell lines and animals have been reported. The present review is focused on giving an overview of the pharmacological activities that have been reported on $B$. prionitis in the past and present.

\section{Antibacterial activity}

Different solvent extracts from leaves and stem parts of B. prionitis L. exhibited antibacterial activity against all Gram-positive bacteria studied (Bacillus pumilus, Bacillus subtilis, Streptococcus pyogenes, and Bacillus cereus) and Gram-negative bacteria (Escherichia coli, Serratia marcescens, Comamonas acidovorans, and Pseudomonas aeruginosa) [12]. Maximum inhibition was delivered by methanol leaf extract against $B$. cereus which was followed by pet ether leaf extract against E. coli. Minimum inhibition was shown by pet ether leaf extract against Alcaligenes faecalis, followed by methanol bark extract against A. faecalis. Antibacterial activity of the various extracts of B. prionitis was compared to the standard antibacterial agent ampicillin, tetracycline, and streptomycin, and it appeared to be almost the same [13]. In another study, the petroleum ether extract of B. prionitis was most dynamic against Pseudomonas putida and B. subtilis. While the ethanol extract of $B$. Prionitis was against $P$. putida [14]. Some antibacterial phytochemicals include balarenone, pipataline, and 
Table 1: Taxonomical classification of $B$. prionitis

\begin{tabular}{ll}
\hline Kingdom & Plantae \\
\hline Sub Kingdom & Tracheobionta \\
Division & Magnoliophyta \\
Class & Magnoliopsida \\
Subclass & Asteridae \\
Order & Scrophulariales \\
Family & Acanthaceae \\
Genus & Barleria \\
Species & Prionitis \\
\hline
\end{tabular}

B. prionitis: Barleria prionitis

\section{Table 2: Vernacular names}

\begin{tabular}{|c|c|}
\hline Sanskrit & Vajradanti, Kurantaka, Koranta \\
\hline Marathi & Kalsunda, kholeta, pivalakoranta \\
\hline Tamil & $\begin{array}{l}\text { Araniyaccokicceti, manjachemulli, mirutam, mituri, } \\
\text { muli, mulli, mulliver, pitakantakacceti }\end{array}$ \\
\hline Kannada & $\begin{array}{l}\text { Gorante, gorantedai, mullu jaali, mullu madarangi, } \\
\text { mullugoranta }\end{array}$ \\
\hline Malayalam & Manjakkanakambaram, Kanakambaram \\
\hline Hindi & $\begin{array}{l}\text { Kanakambar, Vajradanti, kat-sareya, katsareya, peela } \\
\text { bansa }\end{array}$ \\
\hline English & Porcupine flower, Crossandra, Barleria \\
\hline
\end{tabular}

13,14-secco-stigmasta-5, 14-diene-3-a-ol have been isolated from the ethanolic extract of $B$. prionitis, and these compounds showed a strong antibacterial activity against $B$. cereus and P. aeruginosa [15].

\section{Antifungal activity}

The methanolic extract of B. prionitis was considered to have a check on Candidiasis and other oral infections, as its bark showed potent activity against the oral fungi such as Saccharomyces cerevisiae, Candida albicans strain 1 , and $C$. albicans strain 2, when compared to the standard drug amphotericin-B [16]. In another investigation, the leaf exudates and leaf tissue sap of $B$. prionitis L. have been assessed for antifungal activities against some fungi such as Curvularia lunata, Curvularia clavata, Alternaria alternata, Nigrospora oryzae, and Cladosporium oxysporum. The percentage inhibition of spore germination was calculated, and result revealed $40-85 \%$ inhibition of all of the species [17]

\section{Antiviral activity}

Iridoid glycosides and three phenylpropanoid glycosides, namely, luteoside $\mathrm{A}$, luteoside $\mathrm{B}$, and luteoside $\mathrm{C}$ were isolated from $\mathrm{B}$. prionitis and shown to have potent in vitro activity against respiratory syncytial virus [18]

\section{Anthelmintic activity}

Aqueous and ethanolic extract of the whole plant of $B$. prionitis exhibited anthelmintic activity using Pheretima posthuma worms in a dose-dependent manner giving the shortest time of paralysis (P) at $50,75 \mathrm{mg} / \mathrm{ml}$ and death (D) with $100 \mathrm{mg} / \mathrm{ml}$ concentration when compared to standard anthelmintic drug albendazole $[19,20]$.

\section{Antifertility activity}

The methanolic root extract of $B$. prionitis L. was given orally to male rats $(100 \mathrm{mg} / \mathrm{d})$. The duration of the study was 60 days, and the extract reduced the fertility of male rats by $100 \%$. Antifertility effects of Barleria appeared to be arbitrated by conflicts in Leydig and Sertoli cells functions, resulting in the physiomorphological events of spermatogenesis. [21] Antispermatogenic activity is also shown by this [22-24]. In another study done by us, an active component $\beta$-sitosterol (BS) was isolated from the methanolic root extract of $B$. Prionitis, and its antifertility potential was evaluated in the male albino rats. The rats were orally administered olive oil (Group-I, control), BS at the dose level of 5 (Group II), 15 (Group III), and $25 \mathrm{mg} / \mathrm{kg}$ body weight (BW) (Group IV) for 60 days. BW was measured weekly. The results exhibited that BS from the roots of $B$. prionitis impairs spermatogenesis and fertility that recommends that BS from B. prionitis can be used for the development of the male contraceptive drug, which has very limited available options [25].

\section{Antioxidant activity}

The antioxidant capacity and the reducing power were found highest in the methanolic leaf and stem extract as inhibitory concentration $\left(\mathrm{IC}_{50}\right)$ values were $63.41 \pm 0.32$ and $81.69 \pm 0.40$, respectively. These results may be due to the presence of phenolic contents such as barlerinoside, shanzhiside methyl ester, barlerin, acetylbarlerin, 7-methoxydiderroside, and lupulinoside [26]. In another study, antioxidant activity of various fractions of $90 \%$ methanolic extract was determined using the 2,2-diphenyl-1-picrylhydrazyl (DPPH) assay. The $\mathrm{IC}_{50}$ value of hexane, chloroform, ethyl acetate, and butanol soluble fractions of methanolic extract was calculated to determine the DPPH radical scavenging property of these fractions, and ascorbic acid was taken as standard. The maximum effect was demonstrated by the ethyl acetate soluble fractions among all. These methanolic extract fractions follow following order ethyl acetate > butanol > chloroform > methanolic > hexane for their antioxidant activity [27]. Antioxidant activity of the ethanol extract and aqueous extract of the whole plant of $B$. prionitis was investigated in another study, and in this DPPH radical, 2,2'-azino-bis(3-ethylbenzothiazoline-6-sulphonic acid) scavenging activity, hydroxyl radical scavenging activity, reducing power assay, and nitrous oxide scavenging activity of various extracts of $B$. prionitis were calculated to evaluate the radical scavenging potential. Ethanol extract was the more effective antioxidant as compared to the aqueous extract. A direct relationship can be concluded between the antioxidant activity and the phenolic content of $B$. prionitis [28], which was determined using Folin-Ciocalteu reagent. Antioxidant activity was observed in some glycosides which have been isolated from the aerial parts of $B$. prionitis, namely, barlerinoside, shanzhiside methyl ester, 6-0-trans-p-coumararoyl-8-0-acetylshanzhiside methyl ester, barlerin, acetylbarlerin, 7-methoxydiderroside, and lupinoside [29]. Antidiabetic activity

Alcoholic extract of leaf and root of B. prionitis was tested for their antidiabetic activity in normal and alloxan-induced diabetic rats, before and 2 weeks after administration of drugs. Effects demonstrated a significant reduction in blood glucose level and glycosylated hemoglobin. A significant increase was observed in serum insulin level and liver glycogen level, whereas the decrease in the BW was arrested by administration of a leaf extract to the animals. This work suggested that alcoholic leaf extract of $B$. prionitis could be considered as one of the comparatively harmless and with fewer side effects herbal drug for the treatment of diabetes mellitus [30]. In another study, the potency of alcoholic and aqueous extracts of leaf, stem, and root was compared with that of chlorpropamide at a dose of 200 and $100 \mathrm{mg} / \mathrm{kg}$, respectively. The blood glucose level was measured calorimetrically. Alcoholic and aqueous extracts of leaf and root caused a significant fall in blood glucose level in diabetic rats. From this study, it was concluded that $B$. prionitis is almost as effective as chlorpropamide in reducing the sugar levels [31].

Glutathione S-transferase, acetylcholinesterase inhibitory activity A new compound, balarenone, along with three known compounds, pipataline, lupeol, and 13,14-seco-stigmasta-5,14-diene-3- $\alpha$-ol was isolated from the ethanolic extract of $B$. prionitis of Sri Lankan origin. All four of these expressed moderate inhibitory activity against the enzymes glutathione S-transferase and acetylcholinesterase [15].

\section{Anticataract activity}

Anticataract activity of B. prionitis was estimated using selenite- and galactose-induced cataract models in a study. The rats in the test gathering were infused with $B$. prionitis $4 \mathrm{hrs}$ before the selenite administration. B. prionitis was administered to the test rats at the dose levels of 200 and $400 \mathrm{mg} / \mathrm{kg}$ orally, and control rats received only vehicle every day. Cataract stages were assessed at normal intervals. Morphological valuation verified that selenite-treated rats exhibits 
increased opacities as compared with normal. A fall in the glutathione level and an increase in the malondialdehyde levels were seen in control rather than normal lenses. These results revealed that the onset and progression of cataract were hindered in selenite and so as in galactoseinduced cataract. Slit-lamp microscopic images proved its anticatract activity, which can be due to its antioxidant potential [32]

\section{Anticancer activity}

The oil prepared with the whole plant is applied externally during the acute stage of cysts in the blood vessels [33]. It shows its effective anticancer properties.

\section{Anti-inflammatory activity}

In a study, various extracts from the $B$. prionitis roots were extracted. These extracts were evaluated for their anti-inflammatory activity using carrageenan-induced rat paw edema at the dose levels of 200 and $400 \mathrm{mg} / \mathrm{kg}$ orally. The aqueous extract was found most active, it was then fractionated into four major fractions, and these fractions were also screened by the same tests. AQSE fractions (FR-IV) of B. prionitis showed maximum percentage inhibition of rat paw edema (52.56\% and 55.76\%) at a dose of 200 and $400 \mathrm{mg} / \mathrm{kg}$, respectively. Anti-inflammatory activity was found to be dose dependent for all four fractions. These results provide a scenario for the use of this plant as an anti-inflammatory agent [34]. In another study, TAF fraction from the methanol-water extract of $B$. prionitis Linn. was evaluated for anti-inflammatory activity against different acute and chronic animal test models. Carrageenan, histamine, and dextran which are known inflammagens had anti-inflammatory effect produced by it. Adrenalectomized rats show normal anti-inflammatory activity that expresses that the effect of fraction "TAF" is not controlled by the pituitary-adrenal axis. "TAF" also showed inhibition of vascular permeability and leukocytes migration in vivo into the site of inflammatory insult. Ibuprofen was used as a standard reference drug [35]. In one study, methanolic extract of B. prionitis Linn. at the dose of $500 \mathrm{mg} / \mathrm{kg}$ showed anti-inflammatory activity in the early stage as well as in the late stage (up to 180 minutes) comparable to control and standard indomethacin [36]

\section{Antinociceptive activity}

One study was undertaken to evaluate the antinociceptive activity of $50 \%$ ethanolic extract of the flower of B. prionitis in experimental animals. The analgesic effect of the extract tested in mice of either sex, using an Ugo Basile Analgesy meter. A significant increase was measured in the analgesio-meter-induced force $(\mathrm{p}<0.01-<0.001)$ at the dose level of 50,100 , and $200 \mathrm{mg} / \mathrm{kg} \mathrm{B}$. prionitis extract and exhibited resistance against pain after 30 minutes equivalent to $26.3-48.23 \%$ protection [37].

\section{Antihypertensive activity}

In a study, antihypertensive activity was evaluated in male albino Wistar rats, which were uninephrectomized. Hypertension was induced by injecting deoxycorticosterone acetate salt, rats were divided into five groups, different dose levels were administered twice a week for the duration of 6 weeks, and instead of water, $1 \% \mathrm{NaCl}$ was provided for drinking to the rats. Dose levels of $200 \mathrm{mg} / \mathrm{BW}$ and $400 \mathrm{mg} / \mathrm{BW}$ showed the maximum antihypertensive effect among all. Significant antihypertensive activity is developed by the alkaloids, flavonoids, steroids, saponins, tannin, and phenolic compounds, whose presence in B. prionitis was confirmed through phytochemical screenings [38].

\section{Cytotoxic activity}

3-(4,5-dimethylthiazol-2-yl)-2,5-diphenyltetrazolium bromide assay on human gingival fibroblast and human dermal fibroblast cell lines for ethanolic extract of $B$. prionitis gave cytotoxicity effects data. The concentration of test needed to inhibit cell growth by $50 \%\left(\mathrm{CTC}_{50}\right)$ value was found to be more than $1,000 \mu \mathrm{g} / \mathrm{ml}$. Chlorhexidine was found to be more cytotoxic with the $\mathrm{CTC}_{50}$ value of $12.5-25 \mu \mathrm{g} / \mathrm{ml}$. Ethanolic extract of $B$. prionitis was found significantly cytotoxic $(\mathrm{p}<0.05)$ in comparison with control [39]. In another study, the methanolic extract of the whole plant of $B$. prionitis was studied for the anticancer activity of the Human Ovarian Cancer Cell Line Ovcar-3 and human renal cancer cell line $786-0$ in different concentrations $(10,20,40$, and $80 \mu \mathrm{g} / \mathrm{ml})$ along with standard drug adriamycin (doxorubicin) (positive control compound). On the basis of the results, we can conclude that these extracts were non-cytotoxic [40].

\section{Hepatoprotective activity}

Iridoid-enriched fraction (IF) from the ethanol-water extract of the aerial parts (leaves and stems) of $B$. prionitis Linn. was evaluated for hepatoprotective activity in various acute and chronic animal test models of hepatotoxicity. It afforded significant hepatoprotection against carbon tetrachloride, galactosamine, and paracetamol-induced hepatotoxicity. Silymarin was used as reference hepatoprotective drug. In the safety evaluation study, the oral lethal dose $\left(\mathrm{LD}_{50}\right)$ was found to be more than $3000 \mathrm{mg} / \mathrm{kg}$, with no signs of abnormalities or any mortality observed for a 15-day period under observation after a single dose of drug administered, whereas intraperitoneal $\mathrm{LD}_{50}$ was found to be $2530 \pm 87 \mathrm{mg} / \mathrm{kg}$. SE $(\mathrm{n}=10)$ in mice. The studies discovered noteworthy and concentration-dependent hepatoprotective potential of "IF" because the maximum altered hepatic parameters which resulted in liver damage of the experimental rodents was reversed by it [41].

\section{Central nervous system (CNS) activity}

CNS activity of the 70\% ethanol extract of leaves of B. prionitis Linn (Acanthaceae) in Swiss albino mice was estimated. General behavior was studied using actophotometer. According to the study, it was observed that the test drug has the stimulant activity. However, in comparison with the standard drug, namely, fluoxetine hydrochloride available in the market, the stimulant activity seemed to be less. Fluoxetine stimulates activity in the animals was found to be $91.93 \%$, whereas the test drug from $B$. prionitis stimulated the animal only by $49.72 \%$. The results suggested that ethanol extract of $B$. prionitis exhibits antidepressant activity in testing animal models [42].

\section{Anti-arthritic activity}

The anti-arthritic potential of ethyl acetate fractions of chloroform extract from leaves of $B$. prionitis was evaluated by successive extraction with chloroform and methanol by the hot Soxhlet extraction method. The chloroform extract was further fractionated with solvent ethyl acetate to obtain EABP. Acute non-immunological and chronic immunological arthritis were induced in rats through formaldehyde and Freund's complete adjuvant, respectively. Then, this fraction was evaluated at two doses 125 and $250 \mathrm{mg} / \mathrm{kg}$, fed to the abovementioned group of rats. Significant inhibition of edema was observed in both acute as well as chronic models in dose-dependent manner. Dose level of $250 \mathrm{mg} / \mathrm{kg}$ showed most potent and significant paw edema inhibition. This finding thus supports the traditional use of $B$. prionitis for rheumatoid arthritis [43].

\section{Larvicidal activity}

Larvicidal activity of various extracts of $B$. prionitis was estimated against the Japanese Encephalitis vector, Culex tritaeniorynchus in Tamil Nadu, India. To identify the active principle present in the promising fraction obtained in Chloroform: Methanol extract. The B. prionitis leaf extracts were tested, employing the World Health Organization procedure against fourth instar larvae of $C$. tritaeniorhynchus, and the larval mortalities were recorded at various concentrations $(6.25 \mu \mathrm{g} / \mathrm{ml})$; the $24 \mathrm{hrs}$ lethal concentration values of the $B$. prionitis leaf extracts were determined following Probit analysis. This investigation proved that $B$. prionitis could be possibly utilized as an important component in the Vector control program for the eradication of different harmful diseases [44].

\section{Mast cell stabilization and membrane protection activity}

Hydroalcoholic whole-plant extract of B. prionitis was tested for the membrane stabilization and mast cell protection activity, the results revealed significant inhibition of the hyposaline-induced erythrocyte membrane hemolysis. Mesenteric mast cells degranulation and 
Table 3: Pharmacological action of Barleria prionitis

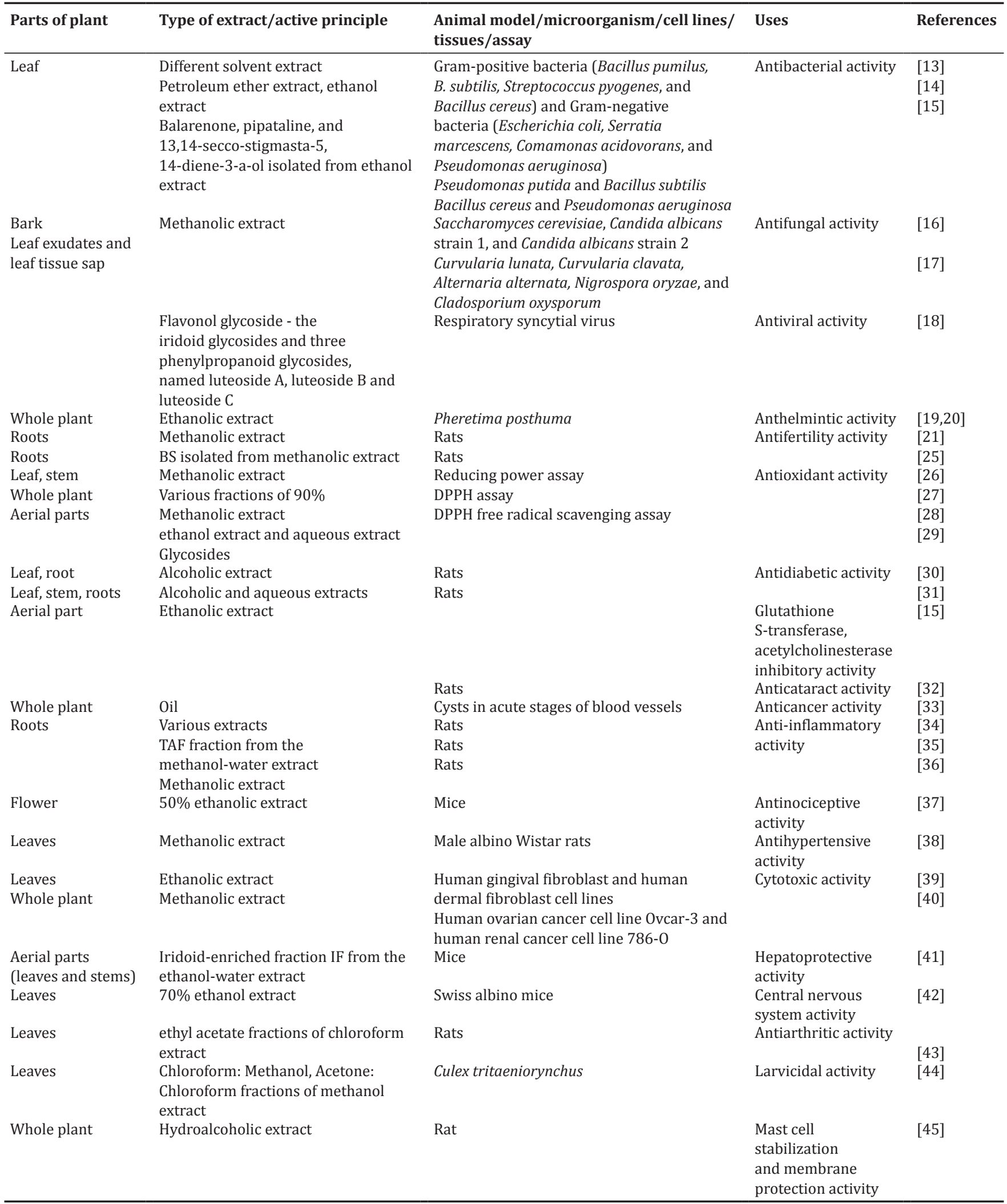

hemolysis of the erythrocytes was significantly reduced in the extracttreated rats [45].

The data on the pharmacological action of $B$. prionitis are listed in Table 3.

\section{PHYTOCONSTITUENTS IN B. PRIONITIS}

Secondary metabolites play an essential role for the economic importance of medicinal plants, although it's not only economical also a core prospective for the betterment of our health. Preliminary 
phytochemical screening showed presence of phytochemicals such as alkaloid (by Mayer's reagent test, Hager's reagent test, Wagner's reagent test, and Dragendorff's reagent test), flavonoids (by alkaline reagent test and Shinoda test), saponins (Frothing test), terpenoids (dinitrophenylhydrazine test), phytosterol (Liebermann's test and Liebermann-Burchard test), phenolic compound and tannin $\left(\mathrm{FeCl}_{3}\right.$, lead acetate test, and bromine water test), essential oil, proteins, and amino acids (Millon's test, Biuret test, and ninhydrin test), carbohydrates (Molisch test, Fehling's solution A, Fehling's solution B, and Benedict's test), glycosides (Borntrager's test and legal's test) [15,28]. Its aerial parts contain glycosides such as barlerinoside, shanzhiside methyl ester, lupulinoside, 7-methoxydiderroside [45] barlerin, acetylbarlerin, and verbascoside [18]; terpenoid such as lupeol, pipataline, and balarenone; and flavones such as apigenin 7-O- $\beta$-D-glucoside [16] and luteolin-7-o-glucoside [45]. Leaves were reported to contain phenolic acids such as Melilotic acid [46], syringic acid, vanillic acid, and p-hydroxybenzoic acid and flavones such as 6-hydroxyflavone and scutellarin [47]. Roots contain phytosterol BS [25]. A brief summary of phytochemical constituents isolated from B. prionitis is given Table 4 .

\section{CONCLUSION}

According to ethnomedical study, B. prionits is very effective and safe for medicinal uses. The qualitative and quantitative analysis reported the presence of many bioactive constituents. Currently, some of the phytoconstituents have been isolated and identified from $B$. prionits. These compounds and crude extracts have been screened for pharmacological activities by in vivo and in vitro models. The structural activity relation between isolated compounds and their target sites in the human body should be meticulously studied further. Analytical characterization of active principle, developing new strategies in clinical trials, and product development will facilitate B. prionits to be considered as a potent herbal drug for the treatment of various chronic diseases in the near future.

Table 4: Phytochemical constituents identified, isolated from Barleria prionitis

\begin{tabular}{|c|c|c|c|c|c|c|}
\hline Phytoconstituents & $\begin{array}{l}\text { Isolated } \\
\text { from }\end{array}$ & Structure & $\begin{array}{l}\text { Molecular } \\
\text { formula }\end{array}$ & Class & Possible activity & Reference \\
\hline Barlerinoside & $\begin{array}{l}\text { Aerial } \\
\text { parts }\end{array}$ & & $\mathrm{C}_{42} \mathrm{H}_{58} \mathrm{O}_{23}$ & $\begin{array}{l}\text { Phenylethanoid } \\
\text { glycoside }\end{array}$ & $\begin{array}{l}\text { Glutathione S-transferase (GST) } \\
\text { inhibitory activity }\end{array}$ & [45] \\
\hline Lupulinoside & $\begin{array}{l}\text { Aerial } \\
\text { parts }\end{array}$ & & $\mathrm{C}_{25} \mathrm{H}_{38} \mathrm{O}_{16}$ & Iridoid diglucoside & Antioxidant activity & {$[45]$} \\
\hline 7-methoxydiderroside & $\begin{array}{l}\text { Aerial } \\
\text { parts }\end{array}$ & & $\mathrm{C}_{20} \mathrm{H}_{30} \mathrm{O}_{13}$ & Secoiridoids & $\begin{array}{l}\text { Antioxidant activity, antiviral } \\
\text { activity }\end{array}$ & [45] \\
\hline Balarenone & $\begin{array}{l}\text { Aerial } \\
\text { part }\end{array}$ & 80 & - & Terpenoid & $\begin{array}{l}\text { Glutathione S-transferase and } \\
\text { acetylcholinesterase inhibitory } \\
\text { activity, antibacterial activity }\end{array}$ & [15] \\
\hline Lupeol & $\begin{array}{l}\text { Aerial } \\
\text { part }\end{array}$ & & $\mathrm{C}_{30} \mathrm{H}_{50} \mathrm{O}$ & Triterpene & $\begin{array}{l}\text { Anti-inflammatory and } \\
\text { anti-cancer, glutathione } \\
\text { s-transferase and } \\
\text { acetylcholinesterase inhibitory } \\
\text { activity, antibacterial activity }\end{array}$ & [15] \\
\hline Melilotic acid & Leaves & & $\mathrm{C}_{9} \mathrm{H}_{10} \mathrm{O}_{3}$ & Phenolic acid & $\begin{array}{l}\text { Antioxidant activity, antiulcer } \\
\text { activity }\end{array}$ & [46] \\
\hline Vanillic acid & Leaves & & $\mathrm{C}_{8} \mathrm{H}_{8} \mathrm{O}_{4}$ & $\begin{array}{l}\text { Dihydroxybenzoic } \\
\text { acid derivative }\end{array}$ & $\begin{array}{l}\text { Anticancer activity, } \\
\text { anti-inflammatory activity, } \\
\text { antioxidant activity, } \\
\text { antinociceptive activity }\end{array}$ & {$[47]$} \\
\hline
\end{tabular}


Table 4: (Continued)

\begin{tabular}{|c|c|c|c|c|c|c|}
\hline Phytoconstituents & $\begin{array}{l}\text { Isolated } \\
\text { from }\end{array}$ & Structure & $\begin{array}{l}\text { Molecular } \\
\text { formula }\end{array}$ & Class & Possible activity & Reference \\
\hline Syringic acid & Leaves & & $\mathrm{C}_{9} \mathrm{H}_{10} \mathrm{O}_{5}$ & Phenolic acid & $\begin{array}{l}\text { Antioxidant activity, anticancer } \\
\text { activity, antimicrobial activity, } \\
\text { antifungal activity, antidiabetic } \\
\text { activity, hepatoprotective } \\
\text { activity }\end{array}$ & [47] \\
\hline 6-hydroxyflavone & Leaves & & $\mathrm{C}_{15} \mathrm{H}_{10} \mathrm{O}_{3}$ & Flavone & $\begin{array}{l}\text { Anti-inflammatory activity, } \\
\text { antioxidant activity, anticancer } \\
\text { activity }\end{array}$ & [47] \\
\hline$\beta$-sitosterol & Roots & & $\mathrm{C}_{29} \mathrm{H}_{50} \mathrm{O}$ & Phytosterols & $\begin{array}{l}\text { Anti-inflammatory activity, } \\
\text { anticancer activity, } \\
\text { anthelminthic activity, cytotoxic } \\
\text { activity, antisteroidogenic } \\
\text { activity, antifertility activity, } \\
\text { antioxidant activity, } \\
\text { antidiabetic activity }\end{array}$ & [25] \\
\hline Scutellarin & Leaves & & $\mathrm{C}_{21} \mathrm{H}_{18} \mathrm{O}_{12}$ & Flavone & $\begin{array}{l}\text { Antioxidant activity, } \\
\text { anti-inflammatory activity, } \\
\text { cardioprotective activity, } \\
\text { hepatoprotective activity, } \\
\text { enzyme inhibitory activity }\end{array}$ & [47] \\
\hline p-hydroxybenzoic acid & Leaves & & $\mathrm{C}_{7} \mathrm{H}_{6} \mathrm{O}_{3}$ & $\begin{array}{l}\text { Phenolic derivative } \\
\text { of benzoic acid }\end{array}$ & $\begin{array}{l}\text { Antimicrobial activity, } \\
\text { anthelmintic activity, } \\
\text { anticancer activity, } \\
\text { antiartherogenic activity, } \\
\text { anti-inflammatory activity, } \\
\text { antiallergenic activity, } \\
\text { antioxidant activity, } \\
\text { antithrombotic activity, } \\
\text { cardioprotective activity }\end{array}$ & [47] \\
\hline $\begin{array}{l}\text { Apigenin } \\
\text { 7-O- } \beta \text {-D-glucoside }\end{array}$ & $\begin{array}{l}\text { Aerial } \\
\text { parts }\end{array}$ & & $\mathrm{C}_{21} \mathrm{H}_{20} \mathrm{O}_{10}$ & Glycosyloxyflavone & $\begin{array}{l}\text { Antibacterial activity, } \\
\text { anti-inflammatory activity, } \\
\text { antioxidant activity }\end{array}$ & [15] \\
\hline Luteolin-7-o-glucoside & $\begin{array}{l}\text { Aerial } \\
\text { parts }\end{array}$ & & $\mathrm{C}_{21} \mathrm{H}_{20} \mathrm{O}_{11}$ & Flavone & $\begin{array}{l}\text { Antibacterial activity, } \\
\text { antioxidative activity, } \\
\text { antimicrobial activity, } \\
\text { hepatoprotective activity, } \\
\text { anti-inflammatory activity }\end{array}$ & [45] \\
\hline Verbascoside & $\begin{array}{l}\text { Aerial } \\
\text { parts }\end{array}$ & & $\mathrm{C}_{29} \mathrm{H}_{36} \mathrm{O}_{15}$ & $\begin{array}{l}\text { Caffeoyl } \\
\text { phenylethanoid } \\
\text { glycoside }\end{array}$ & $\begin{array}{l}\text { Antimicrobial activity, } \\
\text { cytotoxicity activity, } \\
\text { anti-inflammatory activity, } \\
\text { antioxidant activity, antiviral } \\
\text { activity }\end{array}$ & [18] \\
\hline Pipataline & $\begin{array}{l}\text { Aerial } \\
\text { parts }\end{array}$ & & $\mathrm{C}_{19} \mathrm{H}_{28} \mathrm{O}_{2}$ & Terpenoid & $\begin{array}{l}\text { Enzyme inhibitory activity, } \\
\text { antioxidant activity }\end{array}$ & [15] \\
\hline
\end{tabular}


Table 4: (Continued)

\begin{tabular}{llllll}
\hline Phytoconstituents & $\begin{array}{l}\text { Isolated } \\
\text { from }\end{array}$ & $\begin{array}{l}\text { Molecular } \\
\text { formula }\end{array}$ & Class & Possible activity \\
\hline Barlerin & $\begin{array}{l}\text { Aerial } \\
\text { Acetylbarlerin }\end{array}$ & $\begin{array}{l}\text { Antioxidant activity, antiviral } \\
\text { activity, anticancer activity, } \\
\text { enzyme inhibitory activity, } \\
\text { antinflammatory activity }\end{array}$ & $\begin{array}{l}\text { [18] } \\
\text { Shanzhisioxidant activity, antiviral } \\
\text { activity, anticancer activity, } \\
\text { enzyme inhibitory activity, } \\
\text { anti-inflammatory activity }\end{array}$ \\
[18]
\end{tabular}

\section{ACKNOWLEDGMENTS}

The authors are thankful to the Centre for Advanced Studies, Department of Zoology University of Rajasthan, Jaipur, for providing necessary facilities and UGC-BSR, New Delhi, for financial support.

\section{REFERENCES}

1. Banerjee D, Maji A, Banerji P. Barleria prionitis Linn: A review of its traditional uses, phytochemistry, pharmacology and toxicity. Res J Phytochem 2012;6:31-41.

2. Vasoya U. Pharmacognostical and physicochemical studies on the leaves of Barleria prionitis (L). Int J Pharm Sci Res 2012;3(7):2291

3. Sharma P, Shrivastava B, Sharma GN, Jadhav HR. Phytochemical and ethenomedicinal values of Barleria prionitis L: An overview. J Harmonized Res Pharm 2013;2(3):190-9.

4. Jain S, Jain R, Singh R. Ethnobotanical survey of Sariska and Siliserh regions from Alwar district of Rajasthan, India. Ethnobot Leafl 2009;1:21

5. Shendage SM, Yadav SR. Revision of the genus Barleria (Acanthaceae) in India. Rheedea 2010;20(2):81-130.

6. Shukla P, Singh A, Gawri S, Alexande A, Sonwane S. In vitro propagation of Barleria prionitis Linn and its antibacterial activity. Int J Pharm Prof Res 2011;2:198-200.

7. Khare CP. Indian Medicinal Plants: An Illustrated Dictionary. $1^{\text {st }}$ ed. New York: Springer Sciences; 2007. p. 82-3.

8. Chopra RN, Nayar SL, Chopra IC. Glossary of Indian Medicinal Plants. New Delhi: CSIR; 1956, p. 33-4

9. Ambasta SP. The Useful Pilants of India. New Delhi: CSIR; 1986

10. Bhalla NP, Sahu TR, Mishra GP, Dakwala RN. . J Econ Taxon Bot 1992;3:23.

11. Jain SK, Defillips RA. Medicinal Plants of India. New Delhi: CSIR; 1991.

12. Patel BK, Chandel BS, Chauhan HC, Patel KB, Parth FM, Patel MV, et al. Evaluation of antibacterial activities of Barleria prionitis Linn. Afr J Microbiol Res 2015;9 Suppl 30:1840-8.

13. Kumar U, Ahmed F, Khanojia P, Kukreja K, Kumari S, Bhat RA. Exploration of antioxidant and antibacterial activity of Barleria prionitis Linn. Int J Curr Microbiol Appl Sci 2013;2(12):585-91.

14. Aiswarya T, Ravikumar R. A comparitive study on phytochemical analysis, antibacterial activity and antioxidant activity of Barleria prionitis leaves extract of petroleum ether and ethanol extract. Int $\mathrm{J}$
Chemtech Res 2014;6 Suppl 5:3025-33.

15. Kalhari KS, Zahida S, Udenigwea CC, Akhtara S, Ata A, Samarasekera R. Glutathione S-transferase, acetylcholinesterase inhibitory and antibacterial activities of chemical constituents of Barleria prionitis. Z Naturforsch 2007;62(b):580-6.

16. Aneja KR, Joshi R, Sharma C. Potency of Barleria prionitis L, bark extracts against oral diseases causing strains of bacteria and fungi of clinical origin. N Y Sci J 2010;3:5-12.

17. Khare D, Tiwari KL. Effect of leaf exudates and leaf tissue sap of Barleria prionitis $\mathrm{L}$, on spore germination of some spices of anamorphic fungi. Int J Res Eng Appl Sci 2016;6(4):1-7.

18. Chen JL, Blanc P, Stoddart CA, Bogan M, Rozhon EJ, Parkinson N, et al. New iridoids from the medicinal plant Barleria prionitis with potent activity against respiratory syncytial virus. J Nat Prod 1998;61:1295-7.

19. Kaur R, Kaur G, Kapoor A. Preliminary phytochemical screening and in vitro anthelmintic activity of whole plant extracts of Barleria prionitis Linn, against earth worms: Pheretima posthuma. World J Pharm Pharm Sci 2015;4 Suppl 7:1340-7.

20. Chavana CB, Hogadeb MG, Bhingea SD, Kumbhara M, Tamboli A. In vitro anthelmintic activity of fruit extract of Barleria prionitis Linn, against Pheretima posthuma. Int J Pharm Pharm Sci 2010;2(3):49-50.

21. Gupta RS, Kumar P, Dixit VP, Dobhal MP. Antifertility studies of the root extract of the Barleria prionitis Linn in male albino rats with special reference to testicular cell population dynamics. J Ethnopharmacol 2000;70:111-7.

22. Pradhan DK, Mishra MR, Mishra A, Panda AK, Behera R, Jha S, et al. A comprehensive review of plants used as contraceptives. Int J Pharm Sci Res 2012;4:148-55.

23. Ravichandran V, Arunachalam G, Subramanian N, Suresh B. Contraception and its significance in traditional system of medicines. Int J Pharm Sci 2009;1 Suppl 1:1-21.

24. Kaur R, Sharma A, Kumar R, Kharb R. Rising trends towards herbal contraceptives. J Nat Prod Plant Resour 2011;1(4):5-12.

25. Singh K, Gupta RS. Antifertility activity of $\beta$-sisolated from Barleria prionitis (1), roots in male albino rats. Int $\mathrm{J}$ Pharm Pharm Sci 2016;8(5):88-96.

26. Sharma P, Sharma GN, Shrivastava B, Jadhav HR. Evaluation of antioxidant potential of Barleria prionitis Leaf and stem. Am J Phytomed Clin Ther 2014;2(11):1177-86.

27. Kapoor A, Shukla S, Kaur R, Kumar R, Lehra KS, Kapoor S. Preliminary phytochemical screening and antioxidant activity of whole plant of Barleria prionitis Linn. Int J Adv Pharm Biol Chem 2014;3(2):410-9. 
28. Chetan C, Suraj M, Maheshwari C, Rahul A, Priyanka P. Screening of antioxidant activity and phenolic content of whole plant of Barleria prionitis Linn. Int J Res Ayurveda Pharm 2011;2(4):1313.

29. Ata A, Bosch SA, Harwanik DJ, Pidwinski GE. Glutathione S-transferase and acetylcholinesterase-inhibiting natural products from medicinally important plants. Pure Appl Chem 2009;79:2269-76.

30. Dheer R, Bhatnagar P. A study of the antidiabetic activity of Barleria prionitis Linn. Indian J Pharmacol 2010;42(2):70.

31. Geetha M, Wahi AK. Antidiabetic activity of Barleria prionitis Linn. J Nat Remedies 2001;1(1):64-6.

32. Atif M, Rahman SA, Ahmed MI, Mahmood SB, Azharuddin M. Anticataract potential of Barleria prionitis, in vivo study. Int J Pharm Pharm Sci 2015;7(2):100-5.

33. Kinjavadekara RS, Sangraha A. Astanga Sangraha (M). New Delhi: Uppal Publishing House; 1998

34. Khadse CD, Kakde RB. Anti-inflammatory activity of aqueous extract fractions of Barleria prionitis L, roots. Asian J Plant Sci Res 2011;1(2):63-8.

35. Singh B, Bani S, Gupta DK, Chandan BK, Kaul A. Anti-inflammatory activity of TAF an active fraction from the plant Barleria prionitis Linn. J Ethnopharmacol 2003;85(2-3):187-93.

36. Singh K, Kaur R, Singh S, Bajwa BS, Prasad DN. Anti-inflammatory activity of Barleria prionitis Linn. J Nat Remedies 2013;13(1):1-3.

37. Marya BH, Bothara SB. Investigation of antihypertensive activity of leaves of Barleria prionitis, in doca salt induced hypertensive rats. Int J Pharm Sci Rev Res 2013;18(2):17-9.

38. Sawarkar HA, Kashyap PP, Pandey AK, Singh MK, Kaur CD. Antimicrobial and cytotoxic activities of Barleria prionitis and Barleria grandiflora: A comparative study. Bangladesh J Pharmacol
2016;11:802-9.

39. Ganesan R, Venkatanarasimhan M,ElankaniP, Shakila R,Ponniahsamy. Cytotoxic studies on selected siddha plants. World J Pharm Sci 2015;3(9):1872-6

40. Singh B, Chandan BK, Prabhakar A, Taneja SC, Singh J, Qazi GN. Chemistry and hepatoprotective activity of an active fraction from Barleria prionitis Linn, in experimental animals. Phytother Res 2005;19(5):391-404.

41. Gangopadhyay A, Malakar J, Ghosh A, Deb J, Dey S, Datta S, et al. The central nervous system activity of Barleria prionitis Linn, on the locomotor activity of Swiss albino mice using actophotometer. Int J Pharm Biol Sci Arch 2012;3(2):403-5.

42. Choudhary M, Kumar V, Gupta PK, Singh S. Anti-arthritic activity of Barleria prionitis Linn, leaves in acute and chronic models in Sprague Dawley rats. Bull Fac Pharm Cairo Univ 2014;52(2):199-209.

43. Jeyasankar A, Premalatha S, Krishnappa K, Elumalai K. Larvicidal activity of Barleria prionitis L (Acanthaceae) against Japanese encephalitis vector, Culex tritaeniorhynchus giles (Diptera: Culicidae). Int J Inf Res Rev 2013;1(2):116-20.

44. Maji AK, Bhadra S, Mahapatra S, Banerji P, Banerjee D. Mast cell stabilization and membrane protection activity of Barleria prionitis L. Pharmacogn J 2011;3 Suppl 24:67-71.

45. Ata A, Kalhari KS, Samarasekera R. Chemical constituents of Barleria prionitis and their enzyme inhibitory and free radical scavenging activities. Phytochem Lett 2009;2 Suppl 1:37-40.

46. Daniel M, Sabnis SD. Chemosystematics of some Indian members of the Acanthaceae proc. Indian Acad Sci Plant Sci 1987;97:315.

47. Daniel M. Medicinal Plants: Chemistry and Properties. $1^{\text {st }}$ ed. USA: Science Publishers; 2006. 